\title{
Uso pedagógico da rede social Facebook: argumentação em ambiente virtual ${ }^{*}$ Pedagogical use of social network Facebook: Arguments in a virtual environment
}

\author{
Leila Tupinambá Silva* \\ Fábia Magali Santos Vieira* ${ }^{* *}$
}

RESUMO: Esta pesquisa analisa as contribuições das redes sociais como recurso pedagógico no desenvolvimento de habilidades relacionadas à produção de textos argumentativos. A partir de dificuldade diagnosticada em turma de $9^{\circ}$ ano de escola da rede pública municipal de Montes Claros - Minas Gerais, com relação à argumentação, e considerando, ainda, o expressivo interesse dos estudantes por tecnologias digitais e sites de redes sociais, surgiu a necessidade de propor um projeto educacional de intervenção que viesse superar ou, ao menos, minimizar as dificuldades verificadas na turma. A práxis, então, consistiu em trabalho desenvolvido a partir do desdobramento ação-reflexão-ação, com abordagem ancorada na teoria interacionista de Bakhtin (1997), estudos teóricos de Coscarelli (2005) e Xavier (2005) sobre o uso das tecnologias no contexto educacional, bem como em apontamentos Recuero (2009), em seu estudo sobre redes sociais na internet, entre outros autores, como Charaudeau (2010) e Koch (1996), e suas contribuições sobre o texto argumentativo. Por meio da criação de grupo fechado no Facebook, verificamos que a rede social, como ambiente que prima pela interatividade, constitui-se como locus de práticas sociodiscursivas, favorecendo, então, o diálogo, a interatividade e a troca de conhecimentos. Levando em consideração os resultados alcançados, foi possível constatar que o trabalho com redes sociais, quando devidamente mediado pelo professor, colabora sobremaneira para promover reflexão e posicionamento crítico.

PALAVRAS-CHAVE: Redes sociais. Interatividade. Produção de textos. Argumentação.

\begin{abstract}
This study analyzes the contributions of social networks as an educational resource in the development of skills related to the production of argumentative texts. Considering the students' increasing interest in digital technologies and social networks, an educational intervention project was proposed with a view to overcoming or at least minimizing the difficulties of argumentation diagnosed in a 9th-grade class of a municipal middle school in the Municipality of Montes Claros, State of Minas Gerais, Brazil. The praxis was built on an action-reflection-action approach based on Bakhtin's (1997) interactive theory, on Coscarelli's (2005) and Xavier's (2005) theoretical studies on the use of technologies in educational context and on Recuero's (2009) study of social networks on the Internet, among others, including Charaudeau (2010) and Koch (1996) and their contributions to the study of argumentative texts. After creating a closed group on Facebook, the social network, as an environment that excels in interactivity, proved to be a locus of social and discursive practices by promoting dialogue, interaction and exchange of knowledge. The results suggest social networks, when properly mediated by the teacher, may contribute to promoting reflection and critical stand.
\end{abstract}

KEYWORDS: Social networks. Interactivity. Text production. Argumentation.

* Este trabalho é baseado na dissertação de mestrado "Redes sociais: possibilidades para desenvolvimento de práticas argumentativas", desenvolvida no âmbito do PROFLETRAS - Mestrado Profissional em Letras, pela Universidade Estadual de Montes Claros (turma 2013).

* Mestre em Letras pelo programa de Mestrado Profissional em Letras - PROFLETRAS - Universidade Estadual de Montes Claros. Especialista em Mídias na Educação (UNIMONTES). Professora de Língua Portuguesa na Educação Básica, nas redes estadual e municipal, em Montes Claros/MG.

* Doutora em Educação FE/UnB. Professora e pesquisadora da Universidade Estadual de Montes Claros Unimontes. 


\section{Introdução}

O presente artigo é resultado de pesquisa realizada no âmbito do PROFLETRAS Mestrado Profissional em Letras, a partir de dificuldade identificada em sala de aula com relação à produção de textos argumentativos. Nessa perspectiva, o trabalho proposto, vinculado à linha da pesquisa Leitura e produção textual: diversidade textual e práticas docentes, teve por finalidade buscar alternativas para minimizar, em turma de $9^{\circ}$ ano do Ensino Fundamental, de escola da rede pública, em Montes Claros - Minas Gerais, problemas relacionados à produção textual, com ênfase nas práticas argumentativas.

Nota-se que, na produção de textos argumentativos, competência linguística bastante apurada se faz necessária e, em geral, os estudantes se esbarram em dificuldades várias, uma vez que precisam assumir um ponto de vista, posicionando-se favoráveis ou contrários a uma tese, com base em argumentos consistentes e de forma persuasiva. Resultados pouco exitosos obtidos em sala de aula atestaram, pois, a dificuldade enfrentada pelos estudantes da turma, quando se deparavam com um tema sobre o qual tinham que manifestar uma opinião e defendêla.

O uso das redes sociais na internet como recurso pedagógico foi, então, uma forma encontrada para atenuar esses problemas. Consideramos, em primeiro lugar, o fato de essas tecnologias interativas serem, atualmente, muito populares entre os jovens e exercerem grande atração sobre eles. Em segundo lugar, temos de ressaltar o potencial das redes de fomentar o diálogo e a interatividade, podendo promover, nesse caso, o desenvolvimento da expressão do aluno, a reflexão e a socialização de ideias. É, ainda, uma forma rápida, acessível e prática de publicar textos, divulgar informações e oportunizar, de forma efetiva, o trabalho com a linguagem, em condições efetivas de produção, recepção e circulação, a partir da concepção de que ela é construída para e por sujeitos sociais.

Nesse contexto, a pesquisa pautou-se na teoria interacionista de Bakhtin (1997), nas concepções de Coscarelli (2005), Xavier (2005), Rojo (2012), Ribeiro e Alvarenga (2010) e Recuero (2009), que versam sobre sociedade midiatizada e sobre o uso das tecnologias no contexto educacional. Ao tratar especificamente sobre os textos argumentativos, valemo-nos dos estudos de Charaudeau (2010), Koch (1996) e Garcia (2004), entre outros. Foi de fundamental importância, também, a observação dos pressupostos dos Parâmetros Curriculares Nacionais - PCN - (BRASIL, 1998), do Conteúdo Básico Comum - CBC - (Minas Gerais, 2008) e da Proposta Curricular de Língua Portuguesa (MONTES CLAROS, 2014). 


\section{Pressupostos teóricos}

No atual contexto educacional, nota-se a necessidade de trazer para a sala de aula não somente instrumentos que favoreçam uma aula mais atrativa, com recursos diferenciados, mas torna-se fundamental, sobretudo, promover um processo ensino-aprendizagem que leve o aluno a pensar, a pesquisar, a se entender como sujeito ativo no processo de cognição, como coautor do conhecimento. A sala de aula precisa, então, apresentar-se como um ambiente que fomenta a interatividade, a troca de informações, a produção de saberes.

A necessidade de transformar a sala de aula em ambiente interativo dialoga com a concepção interacionista defendida por Bakhtin (1997). O autor defende a comunicação como processo interativo, que não se limita à transmissão de informações, mas que se configura como forma de ação entre os sujeitos, ou seja, como forma de interação social.

A verdadeira substância da língua não é constituída por um sistema abstrato de formas linguísticas nem pela enunciação monológica isolada, nem pelo ato fisiológico de sua produção, mas pelo fenômeno social da interação verbal, realizada através da enunciação ou das enunciações. A interação verbal constitui assim a realidade fundamental da língua. (BAKHTIN, 1997, p. 123)

O tratamento do texto, no ensino de língua materna, então, deve ser norteado por uma concepção de linguagem diferenciada, menos reducionista e mais diversificada. A produção da linguagem é uma atividade essencialmente interativa e, sob essa perspectiva, o fenômeno social da comunicação verbal deve ser tratado com primazia em todo o processo ensinoaprendizagem, priorizando as múltiplas práticas sociais como forma de se produzir conhecimento.

Nessa linha de pensamento, Koch (2009, p. 32-33) analisa a concepção interacional (dialógica) da língua esclarecendo que,

[...] na concepção interacional (dialógica) da língua, na qual os sujeitos são vistos como atores/construtores sociais, o texto passa a ser considerado o próprio lugar da interação e os interlocutores, sujeitos ativos que dialogicamente - nele se constroem e nele são construídos. A produção de linguagem constitui atividade interativa altamente complexa de produção de sentidos, que se realiza, evidentemente, com base nos elementos linguísticos presentes na superfície textual e na sua forma de organização, mas que requer não apenas a mobilização de um vasto conjunto de saberes (enciclopédia), mas a sua reconstrução e a dos próprios sujeitos - momento da interação verbal. 
Koch (1996, p. 17) salienta que a linguagem deve "ser encarada como forma de ação, ação sobre o mundo dotada de intencionalidade, veiculadora de ideologia, caracterizando-se, portanto, pela argumentatividade". Assim, em consonância com a autora, o homem, constantemente, avalia, julga e critica, isto é, forma juízos de valor; por outro lado, por meio do discurso - ação verbal dotada de intencionalidade -, tenta influir sobre o comportamento do outro ou fazer com que compartilhe determinadas opiniões. Destaca, portanto, que a interação social por intermédio da língua é caracterizada, fundamentalmente, pela argumentatividade. Como a autora defende que a neutralidade é um mito, uma vez que o ato de argumentar constitui-se em todo e qualquer ato linguístico fundamental, observa que, até nos textos narrativos e descritivos, a argumentatividade se faz presente em maior ou menor grau.

Defensores do interacionismo sociodiscursivo, Schneuwly e Dolz (2004), ao fazerem um agrupamento dos gêneros conforme os seus aspectos tipológicos (narrar, relatar, argumentar, expor e descrever), apontam que o argumentar tem como domínio social de comunicação a discussão de problemas sociais controversos e, como capacidade de linguagem dominante, a sustentação, a refutação e a negociação de tomadas de posição. Os autores citam como exemplos de gêneros orais e escritos dessa tipologia: textos de opinião, diálogo argumentativo, carta de leitor, carta de reclamação, carta de solicitação, deliberação informal, debate regrado, assembleia, discurso de defesa e de acusação, resenha crítica, artigos de opinião, editorial e ensaio.

Charaudeau (2010, p. 10) em Linguagem e discurso enfatiza que o texto argumentativo "está em contato com um saber que leva em conta a experiência humana, através de certas operações de pensamento", e acrescenta que a argumentação dirige-se à parte do interlocutor que raciocina (capacidade de refletir e de compreender). O sujeito que argumenta passa pela expressão de uma convicção e de uma explicação que tenta transmitir ao interlocutor, para persuadi-lo a modificar o seu comportamento. Segundo o autor, a "argumentação define-se, portanto, numa relação triangular entre um sujeito argumentante, uma proposta sobre o mundo e um sujeito-alvo" (CHARAUDEAU, 2010, p. 205).

Para Koch (1996), no ensino da língua, a preocupação básica não deve ser levar ao aluno somente o conhecimento da gramática de sua língua, mas, sobretudo, conduzi-lo ao desenvolvimento da capacidade de refletir, de maneira crítica, sobre o mundo que o cerca e, em especial, sobre a utilização da língua como instrumento de interação social. Esclarece que, para tanto, é necessário que ele se torne apto a compreender, a analisar, a interpretar e a produzir 
textos verbais. Garcia (2004), ao tratar da argumentação, esclarece que ela tem o objetivo de formar a opinião do leitor ou ouvinte, tentando convencê-lo, persuadi-lo ou influenciá-lo, mediante a apresentação de razões, em face da evidência das provas e à luz de um raciocínio coerente e consistente. Defende a ideia de que a argumentação deve ser construtiva, cooperativa e socialmente útil, e salienta que esse tipo de texto, não raro, desvirtua-se, degenerando-se em "bate-boca" estéril, falacioso ou sofístico. O esclarece ainda que a argumentação tem como esteio dois elementos principais: a consistência do raciocínio e a evidência das provas. No caso da evidência, salienta que há cinco tipos mais comuns: os fatos propriamente ditos, os exemplos, as ilustrações, os dados estatísticos e o testemunho.

\subsection{Sala de aula: um espaço de multiletramentos}

No contexto educacional, a efetiva inserção das tecnologias ainda é um assunto que gera inseguranças e incertezas. Embora as TIC - Tecnologias da Informação e Comunicação - já sejam aceitas no meio educacional como forma de atrair a atenção dos estudantes e oportunizar maneiras diferenciadas de se ensinar e de se aprender, é notório que elas provocam ainda dúvidas e receios quanto à sua significativa utilização.

Coscarelli (2005, p. 25), ao tratar sobre alfabetização e letramento digital, esclarece que a escola precisa estar atenta às mudanças que se emanam na sociedade e acrescenta que o uso das tecnologias como recurso pedagógico pode se configurar como uma possibilidade de despertar maior interesse do estudante para o conteúdo trabalhado em sala de aula, sobretudo nos tempos atuais, em que os recursos tecnológicos são parte integrante do cotidiano dos indivíduos. A autora assinala a necessidade de se perceber "que a informática pode ser de grande valia para a escola", ressaltando, entretanto, que ela não vai tomar o lugar do professor nem vai fazer mágica na educação. Para Ribeiro e Araújo (2009, p. 167), é inconteste o fascínio que as tecnologias exercem sobre a vida das pessoas e salientam que

[...]tem sido cada vez mais comum observar as pessoas resolverem muitos problemas cotidianos através de mensagens trocadas pelo celular, de operações digitais em caixas eletrônicos das agências bancárias, ou do acesso à internet. Dessas práticas, a internet parece ser a que mais atrai pessoas de todas as idades.

Os autores destacam que não somente adultos, mas também jovens e principalmente crianças, são atraídos cada vez mais pelos aparatos tecnológicos, sobretudo quando estão 
ligados à rede mundial de computadores. Atentar-se para essa realidade é, pois, tarefa da escola, que não pode se manter à margem das inovações ou em muros fechados para essa realidade, mas deve considerar que o letramento digital deve ser levado a sério, pois veio para ficar (MARCUSCHI, 2010).

Xavier (2005) afirma ser salutar conduzir os estudantes a um consumo crítico dos aparatos tecnológicos, como forma de evitar que estes se tornem objetos de desejo obsessivo e até ostentação histérica. Nesse sentido, o autor destaca:

É preciso tornar os usuários das novas Tecnologias da Informação e Comunicação (TICs) conscientes da produtividade potencial constitutiva desses equipamentos tecnológicos e ao mesmo tempo evitar que se transformem em meros consumidores deslumbrados das recém-criadas máquinas mediadoras de comunicação. (XAVIER, 2005, p. 2)

Para ele, as TIC engendram novas formas de ensinar e aprender, pois os artefatos tecnológicos, mais do que incrementar a prática pedagógica, precisam ser utilizados para auxiliar a aprendizagem dos indivíduos, ou seja, é necessário que os sujeitos-aprendizes aprendam a lidar com as informações e saibam aplicá-las em sua formação de maneira crítica, interativa e multidimensional.

Xavier (2005) destaca que, no atual contexto, diferentemente das concepções tradicionais de ensino, que preconizavam uma prática transmissiva e instrutivista, a escola precisa adotar uma mudança de concepção radical e assumir uma aprendizagem (re)construcionista, favorecendo uma nova relação do aprendiz com o conhecimento. O autor ainda elucida que para se garantir a condição de aprender são necessárias três habilidades centrais: autonomia, criticidade e criatividade. Ressalta que é necessário despertar no aprendiz hodierno o refinamento crítico, a fim de que possa buscar por si próprio as estratégias que lhe possibilitem a aquisição de novos saberes e analisar, com senso crítico, as potencialidades e fragilidades do objeto pesquisado.

Briggs e Burke (2004), ao abordarem o sistema de mídias, esclarecem que a mídia precisa ser vista como um sistema em contínua mudança, no qual elementos diversos desempenham papéis de maior ou menor destaque. Conforme esses historiadores, os meios de comunicação devem ser entendidos como interdependentes, tratando-os qual um pacote, um repertório, um sistema. Isso implica que, nem sempre, uma mídia vem para substituir outras, mas para complementar. 
Pensar em termos de um sistema de mídia significa enfatizar a divisão de trabalho entre os diferentes meios de comunicação disponíveis em um certo lugar e em um determinado tempo, sem esquecer que a velha e a nova mídia podem e realmente coexistem, e que diferentes meios de comunicação podem competir entre si ou imitar um ao outro, bem como se complementar. (BRIGGS; BURKE, 2004, p. 31)

Ribeiro (2008, p. 24), assim como Briggs e Burke (2004), defende que, com as novas tecnologias, o sistema de mídias sofre uma reconfiguração, que é, gradativamente, apropriada pelos leitores/usuários. A autora esclarece, contudo, que não se trata "de uma 'revolução', movimento abrupto, mas de uma continuidade cheia de parentescos e reconfigurações".

No contexto educacional, então, os diversos recursos midiáticos devem se somar, na tentativa de oferecer diferentes formas de ensino, favorecendo, assim, os multiletramentos. Rojo (2012) chama a atenção para o fato de as mudanças sociais, culturais e tecnológicas exigirem novas formas de letramento, pois requerem que os sujeitos façam uso eficiente dos mais diversos suportes e arranjos textuais, em práticas discursivas que envolvem novas ferramentas - além das da escrita manual (papel, lápis, caneta, giz e lousa) e impressa (tipografia e imprensa) - de áudio, vídeo, tratamento da imagem, edição e diagramação. A autora defende uma pedagogia dos multiletramentos, enfatizando que, ao invés de impedir o uso do internetês, é possível investigar as causas e os modos desse tipo de escrita. Sugere também que, ao invés de se proibir o celular em sala de aula, o professor poderia usá-lo para a comunicação, a pesquisa, a filmagem e a fotografia.

A escola, nessa conjuntura, como agência de letramento, embora tenha a necessidade de ensinar o Português padrão, não pode ignorar a existência de outras variedades, como o internetês, por exemplo; deve trabalhar com excelência a modalidade escrita, sem, contudo, menosprezar o desenvolvimento da expressão oral dos educandos. Assim, caso se almeje, de fato, formar estudantes que deem conta de adaptar o uso da língua de acordo com o contexto situacional, é papel das instituições de ensino oferecer diversificadas situações de convívio com os variados suportes, tipos e gêneros textuais, presentes em mídias tanto impressas quanto digitais, na modalidade escrita, mas também oral.

\subsection{Redes sociais na escola: potencialidades pedagógicas}

Em consonância com concepções que consideram a necessidade de tornar a sala de aula um ambiente em que a linguagem seja, de fato, interativa e que os alunos autores se percebam 
como seres sociais que atuam não apenas como espectadores, mas como produtores do saber, como coautores do conhecimento, de forma cooperativa, o trabalho com sites de redes sociais ganha relevo especial.

Gomes et al. (2011, p. 236) definem redes sociais como "ambiente baseado no pressuposto de que cada usuário possui conhecimentos e, através da colaboração e comunicação, pode-se gerar um conhecimento do grupo que não pode ser atribuído a uma única pessoa". O trabalho com redes sugere, pois, participação e cooperação dos sujeitos envolvidos, propiciando colaboração e integração, por meio de um ambiente em que é possível interagir, trocar conhecimento e (com)partilhar informações.

O uso de redes sociais como recurso pedagógico se configura, então, como forma de potencializar o diálogo, a interação e a interatividade, uma vez que esse espaço se constitui como locus de construção colaborativa (síncrona e assíncrona) de relacionamentos e de conhecimentos. Recuero (2009), em Redes sociais na internet, faz um estudo sobre sites de redes sociais, seu impacto na sociedade atual e as suas implicações nas formas de comunicação e de sociabilidade. Segundo a autora,

Sites de redes sociais propriamente ditos são aqueles que compreendem a categoria dos sistemas focados em expor e publicar as redes sociais dos atores. São sites cujo foco principal está na exposição pública das redes conectadas aos atores, ou seja, cuja finalidade está relacionada à publicização dessas redes. É o caso do Orkut, do Facebook, do Linkedin e vários outros. São sistemas onde há perfis e há espaços específicos para a publicização das conexões com os indivíduos. (RECUERO, 2009, p. 104)

A autora esclarece que é a partir da década de 90 que o estudo das redes sociais ganha destaque como metáfora estrutural para a compreensão dos grupos expressos na internet, em que atores podem se construir, interagir e comunicarem-se com outros. Elucida também que uma rede social é constituída como um conjunto de dois elementos: atores (pessoas, instituições ou grupos; os nós da rede) e suas conexões (interações ou laços sociais).

No caso específico da rede social Facebook, Recuero (2009, p. 172) esclarece que

[...] é hoje um dos sistemas com maior base de usuários no mundo. [...] O Facebook funciona através de perfis e comunidades. Em cada perfil, é possível acrescentar módulos de aplicativos (jogos, ferramentas etc.). O sistema é muitas vezes percebido como mais privado que outros sites de redes sociais, pois apenas usuários que fazem parte da mesma rede podem ver o perfil uns dos outros. 
Ribeiro e Alvarenga (2010), no texto "O professor e o avatar do professor nas redes sociais", esclarecem que redes sociais sempre existiram, independentemente das tecnologias digitais, mas acrescentam que essas redes "certamente se equipam com a ajuda de ambientes como o Orkut, o Twitter ou o Facebook. As relações entre as pessoas parecem se multiplicar, já que os vínculos tornam-se mais visualizáveis” (RIBEIRO; ALVARENGA, 2010, p. 2). Esses estudiosos chamam a atenção para o fato de o professor se deparar, cada dia mais, com a cobrança de que esteja em rede e, ainda, com a necessidade de trabalhar em sala com computadores e aparelhos digitais, a fim de ser, de fato, um operador de letramento digital. Os autores ressaltam que, embora não haja uma teoria conclusiva, há a premissa de que as tecnologias digitais nas salas de aula trazem grandes contribuições para o processo ensinoaprendizagem. E destacam algumas delas:

[...] podem melhorar o ensino, transformar abordagens e conteúdos, dinamizar aulas, animar docentes e discentes, interessar uma geração supostamente menos atenta às aulas e que dispõe de mais motivos para se distrair, para se interessar pela aprendizagem de conteúdos e ferramentas que estão do lado de fora dos muros da instituição. (RIBEIRO; ALVARENGA, 2010, p. 23)

Lorenzo (2011), por sua vez, menciona o Facebook como a maior rede social do planeta e discorre sobre as muitas formas de trabalho com as redes sociais na educação, destacando a escrita colaborativa, as videoaulas, os fóruns de discussão, o contato com personalidades, a conversa com autoridades, os jogos educativos, as questões de exame, o esclarecimento de dúvidas, as datas de interesses da classe, as instruções sobre tarefas, as dicas para a elaboração e a entrega de trabalhos, além de possibilidades de compartilhar informações, consultar notas e resultados de trabalhos, participar de enquetes etc. Para o autor, no entanto, o maior progresso proporcionado por esses sites é o fato de viabilizar o estudo em rede:

Mais de cinco milhões de estudantes brasileiros já pertencem a uma rede de relacionamento na internet, como o Facebook ou o Twitter. A novidade é que, agora, parte deles começa a conviver com esses círculos virtuais incentivados pela própria instituição de ensino - e com fins educativos. Algumas escolas, a maior parte privada, fazem utilização simples dessas redes sociais, inserindo ali dados como avisos e calendário de aulas. Muitas vezes, colocam ainda exercícios e o conteúdo das aulas, meio que vêm proporcionando a aproximação dos pais da vida escolar. [...] O maior progresso proporcionado por essas redes sociais, no entanto, se deve à possibilidade que elas abrem para o ensino em rede. No ambiente virtual, os estudantes debatem, sob a orientação de um educador, temas exibidos na sala de aula. (LORENZO, 2011, p. 56) 
Essa possibilidade de debate em ambiente virtual destacada por Lorenzo (2011), como forma de gerar discussão de temas trabalhados e discutidos em sala, vai ao encontro do que nos propusemos a realizar neste trabalho, levando-se em consideração que o desenvolvimento de práticas argumentativas é o escopo de nosso estudo.

\section{Metodologia}

A pesquisa apresentada, cuja finalidade foi analisar as contribuições das redes sociais no desenvolvimento de práticas argumentativas, utilizou como método a pesquisa-ação (THIOLLENT, 2005),, pois tivemos como foco a reflexão sobre a prática pedagógica e os problemas nela encontrados, de forma a intervir, de maneira consciente e embasada teoricamente, na tentativa de superar ou, ao menos, minimizar os problemas então diagnosticados na prática docente.

À luz dos fundamentos da pesquisa-ação, buscamos atuar com base em diagnóstico realizado em escola da rede pública de Montes Claros/MG, referente às dificuldades relacionadas à produção de textos argumentativos. O universo de nosso estudo foi composto por 21 alunos do $9^{\circ}$ ano, com faixa etária entre 14 e 16 anos.

A práxis, nesse caso, consistiu em trabalho desenvolvido a partir do desdobramento ação-reflexão-ação, envolvendo ações sistemáticas e pontuais, sempre respaldadas em estudos e pesquisas já realizados sobre o tema. Consideramos que refletir sobre as estratégias utilizadas e sobre as ações realizadas permite-nos "atualizar e compreender o passado, fazer da memória uma forma de conhecimento. Implica saber corrigir erros, reconhecer acertos, compensar e antecipar nas ações futuras o que se pôde aprender com as ações passadas" (MACEDO, 2002, p. 13).

Esta pesquisa utilizou como procedimentos técnicos a pesquisa bibliográfica, realizada com base em material já divulgado sobre os temas abordados, sobretudo em livros e artigos científicos, e a pesquisa documental, que consistiu na análise dos documentos oficiais de Língua Portuguesa (BRASIL, 1998; MINAS GERAIS, 2008; MONTES CLAROS, 2014), em relação aos objetivos e orientações sobre o trabalho com o texto argumentativo.

Como instrumentos de coleta de dados, utilizamos a observação participante e o questionário, bem como Projeto Educacional de Intervenção (PEI), por meio do qual coletamos três corpora para análise de dados: uma produção inicial (P1), os logs que compuseram a 
participação dos alunos em grupo fechado na rede social Facebook, intitulado Ponto de vista e uma produção final (P2).

$\mathrm{Na}$ análise dos dados desta pesquisa, utilizamos, em alguns momentos, uma abordagem quantitativa (uma vez que os dados foram, em determinados casos, transformados em números, para construção de gráficos e tabelas), mas ênfase foi dada à abordagem qualitativa, haja vista que o nosso enfoque foi a análise e interpretação dos dados, com vistas à observação da situação da turma antes, durante e após a aplicação do projeto educacional de intervenção, para verificação dos resultados alcançados.

\section{Resultados}

Como já foi explicitado, a fim de constatar as reais dificuldades dos estudantes e acompanhar os possíveis avanços, tomamos como corpus duas produções de texto do tipo argumentativo, realizadas pelos estudantes em sala, durante a aplicação do Projeto Educacional de Intervenção, as quais denominamos produção inicial (P1) e produção final (P2) e, também, os $\operatorname{logs}$ que compuseram a participação dos alunos no grupo Ponto de vista em postagens realizadas ao longo do trabalho. Nesse sentido, apresentamos, a seguir, os procedimentos de análise desses corpora e seus respectivos resultados.

\subsection{Corpus 1: A produção inicial - P1}

A primeira atividade de produção de texto aplicada no projeto educacional de intervenção, discutindo o tema "Uso das tecnologias e sua influência nas relações interpessoais" foi coletada, para que, por meio desse corpus, pudéssemos analisar as reais dificuldades dos alunos no que se refere à argumentação.

Nesse contexto, solicitamos aos 21 estudantes da turma que realizassem uma produção de texto do tipo argumentativo sobre o assunto debatido em sala. Nosso objetivo foi, portanto, constatar, por meio dessa atividade, as dificuldades dos alunos, para que, após atividades previstas neste Projeto Educacional de Intervenção, pudéssemos verificar se foi possível superar (ou ao menos minimizar) as dificuldades diagnosticadas na turma com relação à produção de textos argumentativos.

Assim, a partir de charge (Figura 1), propusemos que os alunos produzissem, com base nas atividades e discussões já realizadas em sala, um texto de opinião sobre o tema "O uso das tecnologias e sua influência nas relações interpessoais". 


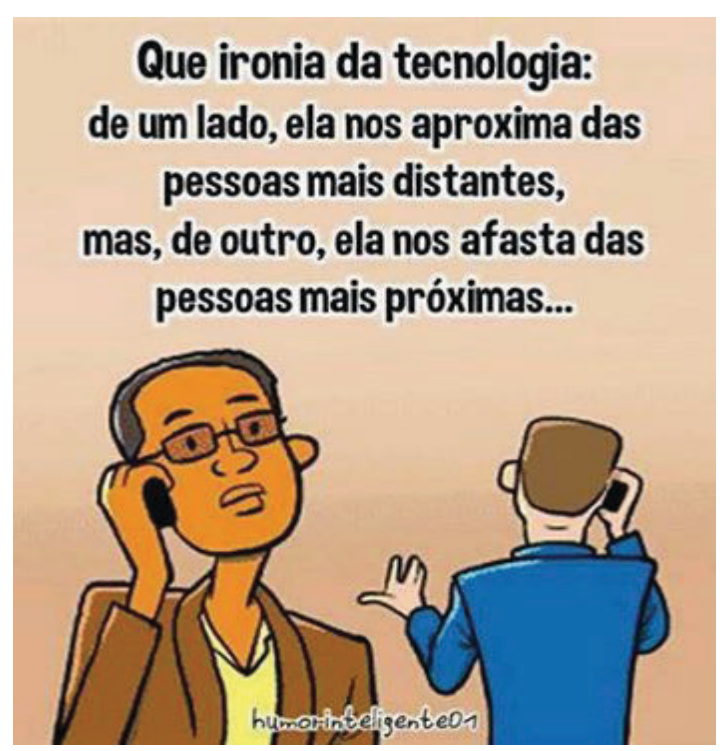

Figura 1 - Imagem atividade (produção inicial)

Fonte: Facebook (2014).

Esclarecemos que o estudante, em seu texto, deveria identificar o ponto de vista apresentado no cartum e posicionar-se a respeito do assunto: expressar sua opinião e defendêla por meio de argumentos. Acrescentamos que o texto deveria apresentar título e ser escrito em linguagem padrão.

A fim de facilitar a análise dos dados, tornando-a menos abstrata, estabelecemos algumas categorias, de forma simples e objetiva, com base nas habilidades propostas para a produção de textos argumentativos no $\mathrm{CBC}$ de Língua de Portuguesa para o Ensino Fundamental, com destaque para duas delas: "Reconhecer e usar as fases ou etapas da argumentação em um texto ou sequência argumentativa" e "Reconhecer e usar estratégias de organização da argumentação em um texto ou sequência argumentativa" (MINAS GERAIS, 2008).

Assim, apresentamos, a seguir, a forma utilizada ${ }^{1}$ para categorizar os textos produzidos pelos estudantes, de acordo com o seu padrão de desempenho.

\footnotetext{
1 Para construção desse quadro, de elaboração própria, tomamos como base a apresentação dos resultados dos alunos do $9^{\circ}$ ano da rede estadual de Minas Gerais no SIMAVE - Sistema Mineiro de Avaliação da Educação Pública (disponível em: < $\underline{\text { http://www.simave.caedufjf.net/wp-content/uploads/2014/07/PROEB-RP-LP-9EF- }}$ WEB.pdf $>$ ), que avalia o padrão de desempenho do aluno, de acordo com seu resultado nas questões da prova de múltipla escolha. Em nosso trabalho, adaptamos esse perfil, explorando habilidades relacionadas, não ao resultado em questões objetivas, mas aos modos utilizados pelo estudante em sua argumentação, com base nas habilidades propostas pelo CBC (MINAS GERAIS, 2009).
} 
Quadro 1 - Categorias utilizadas para análise dos corpora P1 e P2

\begin{tabular}{|lll|}
\hline \multicolumn{1}{|c}{ BAIXO } & INTERMEDIÁRIO & \multicolumn{1}{c|}{ RECOMENDADO } \\
\hline $\begin{array}{l}\text { 1) NÃO USA (ou usa com } \\
\text { dificuldades) as fases ou } \\
\text { etapas da argumentação } \\
\text { em um texto ou sequência } \\
\text { argumentativa; }\end{array}$ & $\begin{array}{l}\text { 1) USA as fases ou etapas } \\
\text { da argumentação em um } \\
\text { texto ou sequência } \\
\text { argumentativa; }\end{array}$ & $\begin{array}{l}\text { 1)USA as fases ou etapas } \\
\text { da argumentação em um } \\
\text { texto ou sequência } \\
\text { argumentativa; }\end{array}$ \\
$\begin{array}{l}\text { 2) NÃO USA estratégias } \\
\text { de organização da }\end{array}$ & $\begin{array}{l}\text { 2)NÃO USA (ou usa com } \\
\text { dificuldades) estratégias } \\
\text { texto ou sequência } \\
\text { argumentativa }\end{array}$ & $\begin{array}{l}\text { 2)USA estratégias de } \\
\text { organização da } \\
\text { argumentação em um texto } \\
\text { ou sequência } \\
\text { argumentação em um }\end{array}$ \\
$\begin{array}{l}\text { texto ou sequência } \\
\text { argumentativa. }\end{array}$ & \\
\hline
\end{tabular}

Fonte: elaboração própria (2015).

Para efeito de demonstração, selecionamos os textos de dois alunos, todos eles classificados no baixo padrão de desempenho. Cumpre-nos esclarecer que, por questões éticas, a identidade dos alunos será preservada. Desse modo, não mencionamos seus nomes e, para identificá-los, optamos por utilizar as iniciais dos sobrenomes.

Tomemos, como primeiro exemplo, o texto do aluno R.M., intitulado "O que eu acho", o qual apresenta problemas quanto à estruturação e organização das ideias.

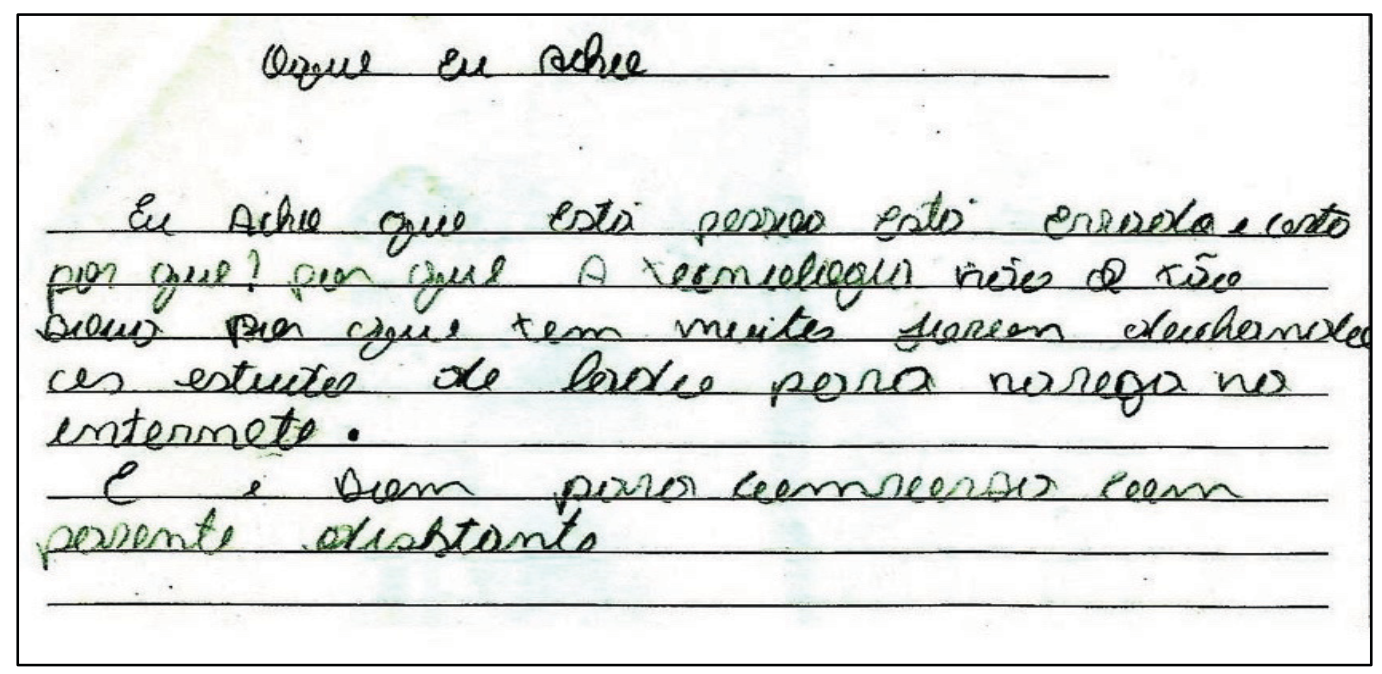

Figura 2 - Produção inicial do aluno R.M.

Fonte: pesquisa empírica (2014).

Notamos que o aluno R.M., em seu texto, emite, mesmo que de forma bem rudimentar, uma opinião sobre o tema discutido: "Eu acho que esta pessoa está errado e certo por que?" [sic]. Entretanto, ao apresentar argumentos para defender seu ponto de vista, foge ao tema proposto. Ele aborda o fato de alguns jovens abandonarem os estudos para "navega na 
internete" [sic], quando o tema discutido era o uso das tecnologias e sua influência nas relações interpessoais, o qual estava evidenciado não apenas na charge mas também na proposta de produção de texto.

O segundo argumento utilizado, "E e bom para conversa com parente distante" [sic], aproxima-se um pouco mais da proposta, mas, ainda assim, apresenta-se desconexo das ideias anteriores e não caracteriza uma argumentação consistente. $\mathrm{O}$ texto não apresenta, ainda, uma conclusão. Dessa forma, notamos que o aluno R.M. não estruturou seu texto de acordo com as fases da argumentação, nem utilizou as estratégias de organização de um texto argumentativo.

O texto a seguir, sem título, do aluno D.M., reflete também a dificuldade em defender uma opinião e argumentar em seu favor.

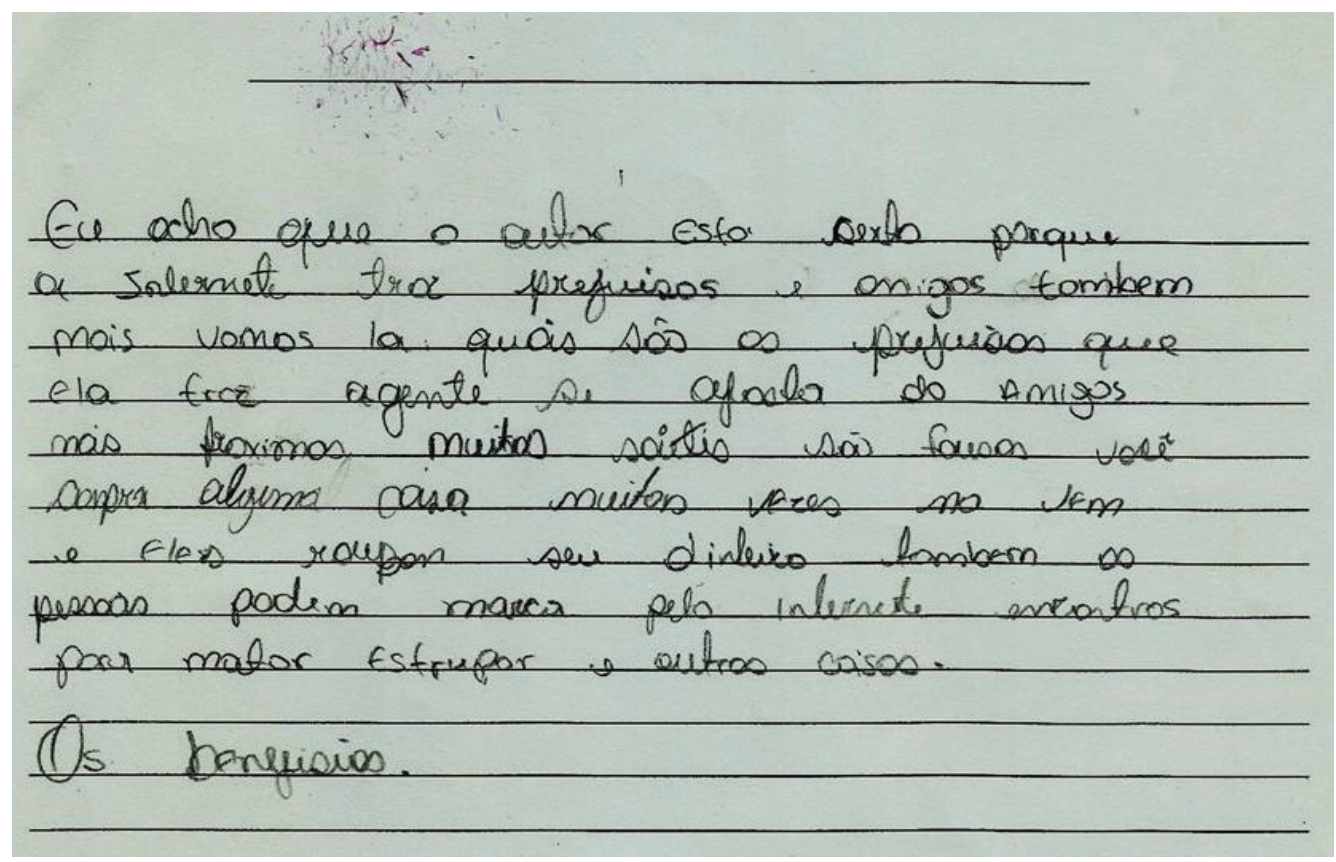

Figura 3 - Produção inicial do estudante D.M.

Fonte: pesquisa empírica (2014).

O aluno D.M. apresenta dificuldades semelhantes às do aluno R.M., pois consegue emitir, de forma simples, seu posicionamento sobre o tema, mas não alcança nenhuma das habilidades propostas para a produção do texto argumentativo. $\mathrm{O}$ aluno concorda com a ideia da charge, quando afirma "Eu acho que o autor esta certo porque a Internet traz prejuisos e amigos também" $[\mathrm{sic}]$. Entretanto, ao tentar organizar o seu texto e trazer argumentos, apresenta tão somente o que ele chama de prejuízos da internet, deixando em branco o espaço reservado 
aos benefícios. E, também, não conclui seu texto. Essas observações nos levam a entender que o estudante não apresentou nenhuma das duas habilidades previstas pelo CBC para produção de um texto argumentativo e, por isso, classificamos o texto no nível baixo.

Apresentamos, agora, em números, a análise geral da turma (Tabela 1). Após observação dos 21 textos, constatamos o seguinte resultado:

Tabela 1 - Produção inicial: desempenho da turma

\begin{tabular}{l|c}
\hline \multicolumn{1}{c|}{ DESEMPENHO } & $\mathrm{N}^{\circ}$ DE ALUNOS \\
\hline Baixo & 12 \\
\hline Intermediário & 07 \\
\hline Recomendado & 02 \\
\hline
\end{tabular}

Fonte: pesquisa empírica.

A análise dos textos revelou um número elevado de estudantes em baixo padrão de desempenho. Isso significa que doze alunos não conseguiam expor, de maneira clara, o seu ponto de vista ou, se o faziam, não conseguiam argumentar em sua defesa e apresentar uma conclusão.

Sete alunos, por sua vez, encontravam-se em nível intermediário, ou seja, utilizavam as etapas da argumentação, mas não usavam (ou usavam com dificuldades) as estratégias de organização da argumentação. Parcela ínfima da turma se encontrava no nível recomendado apenas dois alunos. Estes conseguiram estruturar o texto em ancoragem, tese, argumentação e conclusão e utilizaram, também, estratégias de organização do texto, como causa e consequência, comparação, exemplificação, argumentação de autoridade, citação, entre outros.

\subsection{Corpus 2: Postagens no grupo Ponto de vista}

O segundo corpus analisado nesta pesquisa foram os $\operatorname{logs}$ coletados no grupo Ponto de $v i s t a$, criado na rede social Facebook. Nossas observações objetivaram verificar as dificuldades dos alunos no que se refere à argumentação, bem como os avanços que, gradativamente, aconteceram no modo de se comunicar e argumentar, por meio das práticas discursivas que ocorreram em rede. Embora tenhamos priorizado, para análise das postagens, uma abordagem qualitativa, ressaltamos que algumas análises quantitativas fizeram parte do nosso estudo e nos permitiram observar, em números, a participação dos alunos no grupo Ponto de vista. 
A construção da Tabela 2 favoreceu uma observação sobre a evolução da participação dos alunos nas postagens realizadas ao longo do mês de novembro de 2014. Em sua construção, consideramos o tema da postagem, o número de visualizações e comentários.

Tabela 2 - Participação dos alunos em rede social

\begin{tabular}{|c|c|c|c|}
\hline $\begin{array}{c}\text { Número da } \\
\text { postagem/data }\end{array}$ & Tema & Visualizações & Comentários \\
\hline $\begin{array}{c}1^{a} \text { postagem } \\
(01 / 11)\end{array}$ & Pontos de vista & 21 & 6 \\
\hline $\begin{array}{l}2^{a} \text { postagem } \\
(04 / 11)\end{array}$ & $\begin{array}{c}\text { Uso das } \\
\text { tecnologias }\end{array}$ & 21 & 17 \\
\hline $\begin{array}{l}3^{a} \text { postagem } \\
(12 / 11)\end{array}$ & Pontos de vista & 21 & 17 \\
\hline $\begin{array}{c}4^{\mathrm{a}} \text { postagem } \\
(13 / 11)\end{array}$ & $\begin{array}{l}\text { Uso das } \\
\text { tecnologias }\end{array}$ & 21 & 18 \\
\hline $\begin{array}{l}5^{a} \text { postagem } \\
(18 / 11)\end{array}$ & $\begin{array}{l}\text { Influência da } \\
\text { televisão }\end{array}$ & 21 & 15 \\
\hline $\begin{array}{c}6^{a} \text { postagem } \\
(19 / 11)\end{array}$ & $\begin{array}{l}\text { Influência da } \\
\text { televisão }\end{array}$ & 21 & 16 \\
\hline $\begin{array}{l}8^{a} \text { postagem } \\
(24 / 11)\end{array}$ & Lei da Palmada & 21 & 13 \\
\hline $\begin{array}{l}9^{a} \text { postagem } \\
(24 / 11)\end{array}$ & Lei da Palmada & 21 & 18 \\
\hline
\end{tabular}

Fonte: pesquisa empírica (2015).

Assim, se considerarmos a participação dos alunos da primeira até a última postagem, podemos identificar que, embora o número de visualizações das postagens tenha se mantido constante (21 visualizações), as participações por meio de comentários foram oscilantes, variando entre seis e dezoito comentários. A observação dos dados revela que $100 \%$ dos alunos pesquisados visualizaram todas as mensagens, ao passo que o número de comentários apresentou variações consideráveis e, de forma geral, revelou progressiva participação dos estudantes.

A primeira postagem analisada, por exemplo, contou com número reduzido de participantes. Como o estudo inicial em sala foi sobre o tema pontos de vista, julgamos oportuno fomentar uma discussão, a partir de um cartum, sobre esse assunto. Embora tenha havido 21 visualizações, apenas cinco alunos fizeram comentários (24\% da turma), em um período de onze dias (intervalo entre a primeira e a última postagem). As poucas participações nessa postagem foram de qualidade pouco satisfatória, uma vez que não trataram com precisão o tema em debate. Observamos que os alunos que participaram restringiram seus comentários a uma análise superficial do cartum postado. De forma geral, não houve, pois, uma reflexão sobre o 
tema em discussão e, tampouco, análise crítica. A discussão se limitou a uma mera observação, sem, contudo, associar o seu conteúdo ao tema discutido (pontos de vista e importância da argumentação).

Em sala, comentamos como se deu a interação nessa primeira postagem, destacando os aspectos positivos e negativos que nela ocorreram. Os alunos justificaram a baixa participação, declarando que estavam envergonhados, pois não tinham ainda o hábito de utilizar as redes sociais para emitir uma opinião ou fazer comentários do tipo expositivo ou argumentativo.

A quinta postagem (tomada aqui para efeito de exemplo) apresentou número considerável de participantes: 21 uma visualizações e 15 comentários. A observação dessas participações revelou aspectos importantes, que certamente contribuíram para a construção do conhecimento dos alunos sobre argumentação.

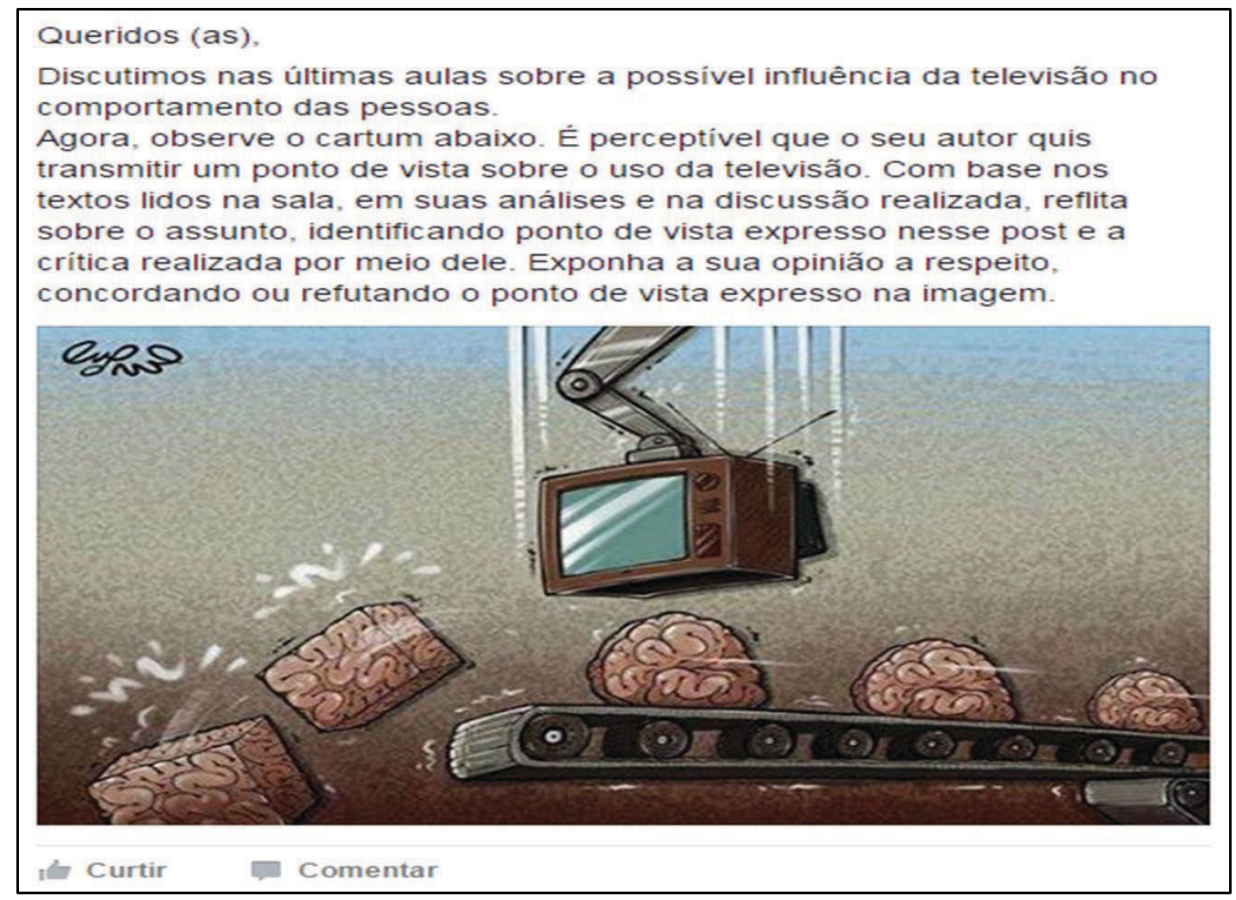

Figura 4 - Postagem Influência da televisão (1)

Fonte: Grupo Ponto de vista, Facebook (2014).

Apresentamos, a seguir, a sequência de comentários nessa postagem².

2 Esclarecemos que foram feitas alterações na formatação do texto transcrito do grupo do Facebook, a fim de seguir a normatização para trabalhos acadêmicos. Entretanto, os comentários dos alunos foram transcritos na íntegra, mantendo sua estrutura e organização. Salientamos que não é objetivo desse trabalho observar fenômenos relacionados à ortografia, regência ou concordância. Assim, desvios da escrita com relação à Norma padrão da Língua Portuguesa não serão considerados/analisados nesta pesquisa, que tem com prioridade o desenvolvimento 
(1) S.D. não entendi o que a imagem quis diser.

(2) L.C. Eu tbm nao entendi.

(3) Professora Não entenderam? Está lançado o desafio: vamos ver quem interpreta a imagem e entende o ponto de vista expresso nela...

(4) S.N. A imagem quis expressar que a televisao esta prendendo o cerebro das pessoas S.D. Mas nao é isto a minha opiniao, a minha opiniao é que a televesao esta sendo so mais uma porta de informacao, mas uma tecnologia que esta avancando, mas como os debates realizados sobre internet nos temos que saber usa-la e saber que o que ela nos expressa.

(5) S.D. não sei se é isso mas.... acho que o autor quis dizer que a tv está moldando a mente das pessoas da forma que ela quer,ou seja influenciando a fazer atos violentos, desonestos e por ai vai...

$[\ldots]$

(6) R.M. gente mais dependi da mente da pessoa nehh//// mais na minha opinião as pessoa esta se levando de acordo com a tv. ves nao acha

(7) S.K. Pelo que entendi o autor quis dizer que a televisão não só influencia mas controla as pessoas que de forma excessiva a utilizam. A partir do momento em que a pessoa cria um vício ela começa a "controlar", seus atos, palavras e as vezes modificam totalmente sua forma de ser, remodelando seu caráter e personalidade.

(8) S.C. Eu comcordo com o autor ele quer passar o quanto as pessoas estao sendo influenciada com a tv q ela estar entrando na mente das pessoas e monitorando os seus pensamentos com seus progamas.

(9) L.M. A televisão esta manipulando os cérebros das pessoas e com isso as pessoas ficam mas violentas, explosivas querem trair seus maridos e esposas e mais brigas dentro de casa de forma que párese ser legal trair e brigar vendo nos filmes e novelas

(10) M.D. Bem acho que para a televisão influenciar nas atitudes dos seres humanos vai muito pro lado picicologico.

Nesse post, podemos notar a presença de teses divergentes quanto ao assunto: enquanto alguns alunos atribuíam à televisão o poder de manipular e influenciar as pessoas negativamente (8 e 9, por exemplo), outros, por sua vez, defendiam que a televisão é apenas mais uma "porta de informação", cabendo aos usuários saber usá-la de forma adequada (4).

Chama-nos a atenção, nesta postagem, a interação e colaboração entre os alunos e suas implicações na construção dos saberes. Nos comentários iniciais (1 e 2), os alunos confessam não ter entendido a imagem apresentada. Percebendo a dificuldade, julgamos oportuno mediar a discussão e realizar, então, uma intervenção, estimulando os alunos a participarem, por meio de um comentário-desafio (3). Logo após, uma aluna demonstra, em sua fala (07), ter entendido a mensagem expressa na charge apresentada. Observamos, então, que a contribuição dessa aluna facilitou a interpretação dos demais, ajudando-os, então, a compreender a ideia

de habilidades relacionadas à produção de textos argumentativos. Não discutiremos, também, o uso do internetês, uma vez que tal assunto foge à proposta do nosso trabalho. 
apresentada no texto e, a partir daí, emitir um ponto de vista sobre o assunto. Os comentários (1) e (5), por exemplo, do aluno S.D., ilustram claramente como a colaboração de outros colegas pode contribuir na construção do conhecimento.

Essas considerações remetem, então, à teoria da cognição distribuída defendida por Hutchins (2010), segundo a qual o conhecimento é construído colaborativamente. Corrobora, ainda, a teoria sociointeracionista de Vygotsky (2002), que preconiza que o indivíduo aprende por meio de sua inserção na sociedade, da sua interação com outros indivíduos e com as ferramentas de seu ambiente.

Sob essa perspectiva, consideramos que as redes sociais são, pois, locus de troca de conhecimentos e colaboração, que favorece, em peso, a construção do conhecimento, pois conforme elucidam Gomes et al. (2011), este ambiente se baseia no pressuposto de que cada usuário possui conhecimentos e, através da colaboração e comunicação, pode-se gerar um conhecimento do grupo que não pode ser atribuído a uma única pessoa.

Por fim, analisaremos agora a postagem número 08 , que teve como temática a Lei da Palmada e apresentou 18 comentários.

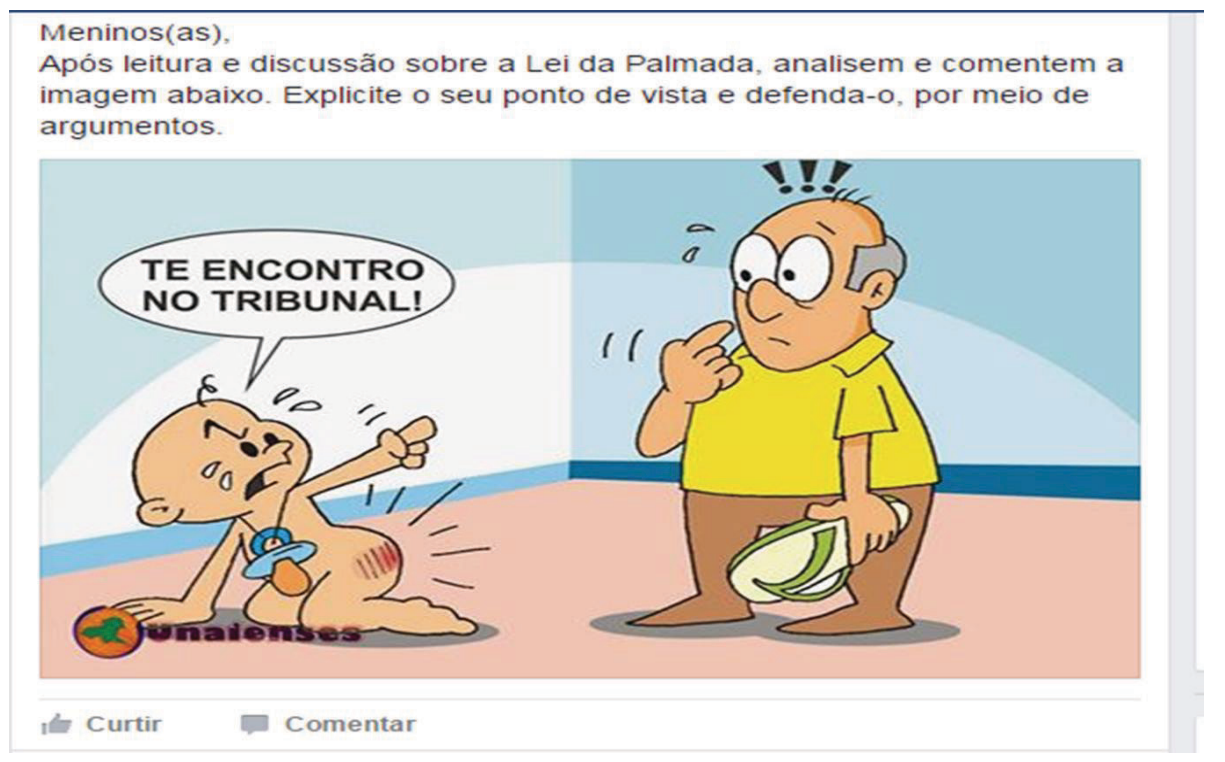

Figura 5 - Postagem Lei da Palmada

Fonte: Grupo Ponto de vista, Facebook (2014).

(11) L.C. pai nao pode corrigir o filho com um tapa q ja e motivo pra ser julgado. Ai na hora $q$ um pai vai corrigir o filho, e ele ja ameaça $q$ vai denunciar e os pais acabam ficando com medo.

(12) S.K. A Lei tem de certa forma tirado toda a autoridade dos pais, a julgar pelo que foi discutido é fácil perceber a mensagem que a imagem quer 
passar. Por causa da "Lei da Palmada" os pais não estão tendo o direito nem de educar seus filhos, o que está se tornando um caso gravíssimo ao analisar o que consequentemente acontece, muitos filhos ainda muito pequenos ( como é apresentado na imagem) usam a lei como uma forma de afronta ao serem corrigidos pelos pais. Por serem amparados pela Lei, acabam usando isso em seu favor, e já existe vários casos percebíveis de filhos que denunciaram ou ameaçaram denunciar os pais ao serem corrigidos pelos mesmos.

(13) S.D. De certa forma eu não concordo com a Lei da Palmada pois, ela está deixando as crianças(até mesmo as mais novinhas) já "espertas" no caso de contrariar os pais,pois elas já tem o argumento que se os seus responsáveis baterem nelas,as mesmas irão chamar a policia e derivados,fora que dar umas palmadas somente para corrigir não é nenhum espancamento,e isto serve para dar limites aos filhos para eles não se perderem no mundo.Agora o governo quer prender os pais por qualquer motivo, as crianças ficam soltas no mundo a fora e quem vai ensinar o caminho certo? o conselho tutelar? A melhor colocação para a Lei da Palmada na minha opinião é somente no caso de espancamento, sangramento, ou formas de agressão com objetos pontiagudos, pesados, cortantes etc. Agora bater com um galho de arvore (pequeno), ou uma palmadinha, ou uma sandália sem arame não faz mal, serve para mostrar que tudo tem limite.

$[\ldots]$

(14) R.N. Muitos acreditam que não é necessário bater para corrigir, é claro que espancar está fora de cogitação mas saber punir é outra coisa.

Para muitas crianças e adolescentes a conversa não basta, é preciso mais que isso, é preciso uma punição mais severa.

Há casos e casos, muitas crianças são fáceis de se controlar, mas outras são um pouco mais hiperativas, dando um pouco mais de trabalho aos pais e educadores. Como já disse a conversa nem sempre surte efeito levando os responsáveis a tomar medidas mais drásticas.

Pode-se perceber claramente em nossos dias como os valores mudaram e consequentemente o caráter das pessoas, afinal o caráter é formado ainda na infância e a educação provinda dos pais deve moldar esse caráter para que no futuro tenhamos pessoas melhores. Quantas pessoas que tiveram uma boa educação ou levaram uma palmada quando criança estão cometendo crimes ou no mundo das drogas? A quantidade é mínima comparada ao que teremos se a forma como as crianças são educadas não mudar, a Lei proíbe qualquer tipo de punição que venha causar trauma na criança, mas duvido se um tapa ou um castigo não mude o conceito ou a forma dessas crianças agirem e pensarem.

(15) R.K. Na minha opinião é que o pai esta assustado com atitude do filho, e eu acho que bater não é o certo ao invés de bater da um castigo para corrigi-lo.

(16) B.E. Na minha opinião os pais devem sim corrigir seus filhos com palmadas para colocar limites nos filho.

(17) A.A. Acredito que a lei deve ser aplicada, porque hoje em dia os pais vivem muito estressados e acabam descontando nos seus filhos, mas por outro lado ela tira a altoridade dos pais de corrigir os filho com uma simples palmada. Enfim a lei nao foi bem elaborada deveria ser especifica para casos mais complexos ou graves.

(18) S.N. Concordo com voce S.K., muitos filhos tem perdido o respeito pelos pais, usando as vezes a lei como forma de desafio. 
A criação da Lei da Palmada gerou muita controvérsia entre a população brasileira e em mim principalmente, afinal a lei pode ser útil para aquelas crianças que são espancadas, mas a lei tem tirado toda a autoridade dos pais, eles não estão podendo nem corrigir mais os filhos, pois se o fizerem serão punidos.

(19) O.L. Na minha opinião deve sim haver a palmada, desde q seja para fim educativo não para o espancamento da criança.

(20) S.K. Eu concordo em alguns pontos,espancar uma criança não é nada certo mas corrigir de forma que eles entendem o erro cometido eu acho que é um direito dos pais...Eu penso que a lei deveria ser aplicada somente em casos em que os pais espancam os seus filhos.

(21) S.A. Na minha opiniao os pais devem corrigir seus filhos de uma maneira severa mais sem bater, porque certos castigos são bem melhores que bater.

$[\ldots]$

A observação da participação dos alunos nessa postagem revela que a argumentação foi se consolidando gradativamente. Nela, foi possível perceber a coexistência de opiniões divergentes, de forma harmônica e respeitável. Percebemos, nessa discussão, três pontos de vista distintos sobre o assunto: alguns são favoráveis à lei e defendem que muitos pais extrapolam e, em situações de descontrole, acabam espancando seus filhos; outros, por sua vez, discordam da Lei, pois consideram que ela tira a autoridade dos pais, que ficam reféns dos próprios filhos e, por fim, aqueles que sugerem que a lei deve ser reformulada, pois se aplica a alguns casos (espancamentos), mas não a outros e acrescentam que as palmadas não devem ser consideradas como crime. Observamos que a argumentação aqui se construiu com o objetivo de convencer ou influenciar os colegas, a partir da apresentação de razões e "à luz de um raciocínio coerente e consistente" (GARCIA, 2004, p. 380).

Ao observar os comentários, podemos constatar que há uma distinção na qualidade. Alguns se limitam a fazer uma análise mais simples, com argumentação bem elementar, restringindo o comentário a um só argumento, como acontece nos exemplos 11, 15, 16, 19 e 21. Entretanto, como professora da turma e conhecedora das dificuldades de muitos estudantes, consideramos como avanço significativo a participação de alguns estudantes, que têm muitas dificuldades para expressar sua opinião. Mesmo que de forma menos elaborada, julgamos então que, para alguns alunos, é um desenvolvimento considerável participar de uma discussão e emitir um posicionamento sobre o tema em discussão.

Outros alunos, por sua vez, trazem uma linguagem mais elaborada, apresentando maior criticidade com relação ao tema, por meio de diferenciados argumentos, discutindo, ainda, as consequências dessa lei na sociedade, tanto na atualidade, como em longo prazo. Na postagem 
em análise, notamos que os comentários (12), (13), (14), (17) e (18), por exemplo, tornaram a discussão mais rica e produtiva, haja vista que, ao apresentarem posicionamentos diferenciados sobre o tema, fizeram uso de diferentes estratégias para respaldar a ideia defendida.

\subsection{Corpus 3: A produção final - P2}

Ao término das atividades propostas no Projeto Educacional de Intervenção, aplicamos uma produção de texto sobre o tema trabalhado e discutido nas últimas aulas: a Lei da Palmada. Nosso objetivo foi, então, coletar dados para contrastar a produção inicial - P1 - com esta produção final - P2, a fim de verificar se, por meio das atividades propostas conseguimos superar (ou ao menos minimizar) as dificuldades dos alunos relacionadas à produção de textos argumentativos.

Ressaltamos que o tema Lei da Palmada foi sugerido pelos alunos, devido a algumas polêmicas que, na época, eram noticiadas em cenário nacional e chamavam a atenção da turma, sobretudo devido ao fato de circularem, em redes sociais, alguns vídeos polêmicos. Assim, realizamos uma retomada dos conhecimentos dos estudantes acerca das especificidades do gênero artigo de opinião e, a partir de uma imagem (Figura 6), solicitamos aos estudantes que, considerando todas as atividades e discussões já realizadas em sala e em ambiente virtual, expusessem, na produção de texto, o seu ponto de vista sobre o tema "Lei da Palmada", defendo-o por meio de argumentos. Esclarecemos ainda que o artigo de opinião produzido deveria apresentar título e ser escrito em linguagem padrão.

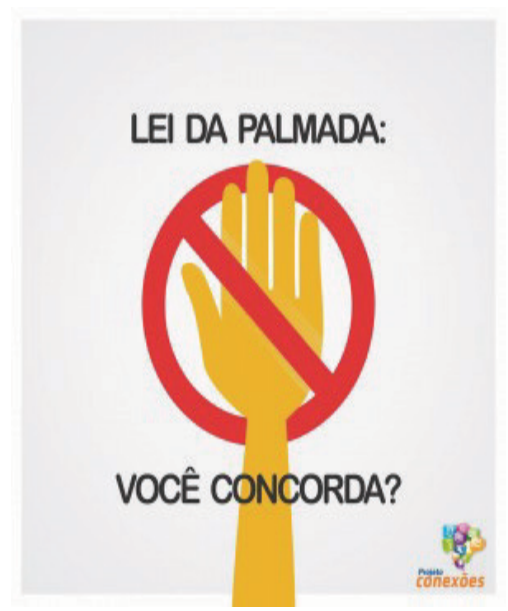

Figura 6 - Imagem produção final - Lei da Palmada

Fonte: PROJETO CONEXÕES. Disponível em: $<$ http://projetoconexoes.com.br/lei-dapalmada-sancionada-um-tapa-na-bunda-da-sociedade/>. Acesso em: 2 dez. 2014. 
É válido esclarecer que, assim como na produção inicial, os alunos foram classificados, em três padrões de desempenho: baixo, intermediário e recomendado (cf. Tabela 1).

Apresentamos, para efeito de exemplificação, o texto da aluna S.K., (representando o nível recomendado), para análise do modo como abordaram o tema e sustentaram o ponto de vista por eles defendido sobre a Lei da Palmada. Nele, a aluna declara ser contra a lei e busca, por meio de argumentos diversos, convencer o leitor de que ela tira a autoridade dos pais e prejudica a educação de crianças e adolescentes. Desde o título, podemos notar a preocupação da estudante em transmitir o seu ponto de vista, tentando impressionar e mostrar ao leitor a pertinência de suas ideias.

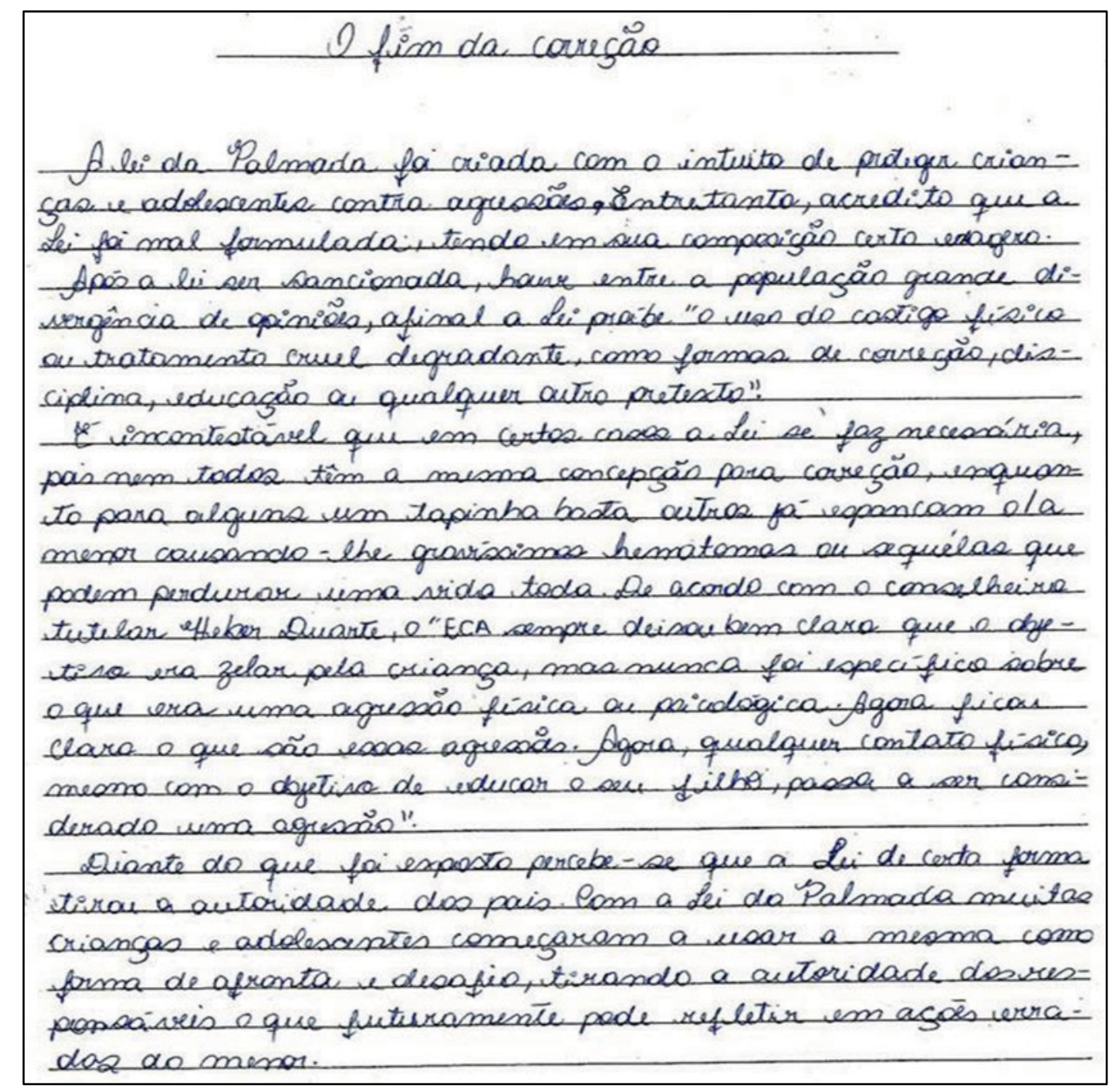

Figura 7 - Produção final - Aluna S.K.

Fonte: pesquisa empírica (2014) 
Ao analisar o texto de S.K., notamos claramente que a aluna se manifesta desfavorável à referida lei. No primeiro parágrafo, no qual ela apresenta a proposição, já é possível perceber o seu ponto de vista quando ela afirma que "a lei foi mal formulada, havendo em sua composição certo exagero".

Nos parágrafos seguintes, há a comprovação de sua tese por meio de argumentos. Para tanto, a aluna utiliza citação da lei ( $2^{\circ}$ parágrafo), contra-argumento e argumento de autoridade ( $3^{\circ}$ parágrafo), que tornam o texto muito bem fundamentado, com argumentação consistente e persuasiva.

Para concluir o texto, a aluna faz uso da estratégia causa-consequência, retomando a opinião apresentada na tese e trazendo reflexões sobre o tema. Aborda os efeitos da Lei da Palmada não somente na atualidade, mas também em longo prazo. O texto da aluna S.K., então, sob nossa análise, classifica-se no nível recomendado, pois argumenta de forma reflexiva, utiliza estratégias de argumentação, bem como apresenta suas ideias e argumentos com criticidade e sequência lógica.

\subsection{Estabelecendo contrapontos}

A análise comparativa dos três corpora revela dados bastante significativos com relação às práticas discursivas que ocorreram, tanto em sala, por meio das produções de textos propostas aos alunos (P1 e P2), quanto em ambiente virtual, no grupo Ponto de Vista. Ao analisar os resultados obtidos, observamos a inconteste evolução no quadro geral da turma no que se refere à argumentação.

Dessa forma, a observação dos dados da produção inicial em relação à produção final revela-nos números que mostram significativo progresso no padrão de desempenho dos alunos, conforme se pode comprovar na Tabela 3.

Tabela 3 - Produção inicial x produção final

\begin{tabular}{ccc}
\hline $\begin{array}{c}\text { Padrão de } \\
\text { Desempenho }\end{array}$ & $\begin{array}{c}\text { Produção } \\
\text { Inicial }\end{array}$ & $\begin{array}{c}\text { Produção } \\
\text { Final }\end{array}$ \\
\hline Baixo & 12 & 02 \\
Intermediário & 07 & 08 \\
\hline Recomendado & 02 & 11 \\
\hline \multicolumn{3}{c}{ Fonte: pesquisa empírica (2015). }
\end{tabular}


É notável que houve, na produção final, uma melhora com relação ao desenvolvimento geral da turma, no que se refere à argumentação. Algumas observações com relação a esses números devem ser destacadas:

i. Enquanto na produção inicial predominavam alunos em baixo padrão de desempenho, correspondendo a $57 \%$ da turma, na produção final, esse número decresceu para $10 \%$;

ii. O nível intermediário manteve-se relativamente estável, mas devemos considerar que, na produção final, essa posição está sendo ocupado por alunos que na P1 estavam em nível baixo e, agora, avançaram para o intermediário. Tais alunos já conseguiram, portanto, produzir texto argumentativo, defendendo uma ideia sobre o tema em debate, e, gradativamente, superando suas dificuldades com relação à construção da argumentação;

iii. O nível recomendado que, na produção inicial, contava com apenas dois alunos, na produção final apresentou acréscimo significativo. $52 \%$ da turma demonstraram, na P2, desempenho satisfatório na produção de textos argumentativos, com as habilidades necessárias para o desenvolvimento da argumentação.

No Gráfico 1, podemos observar, com mais precisão, a evolução da turma no que se refere ao desenvolvimento de habilidades relacionadas à argumentação.

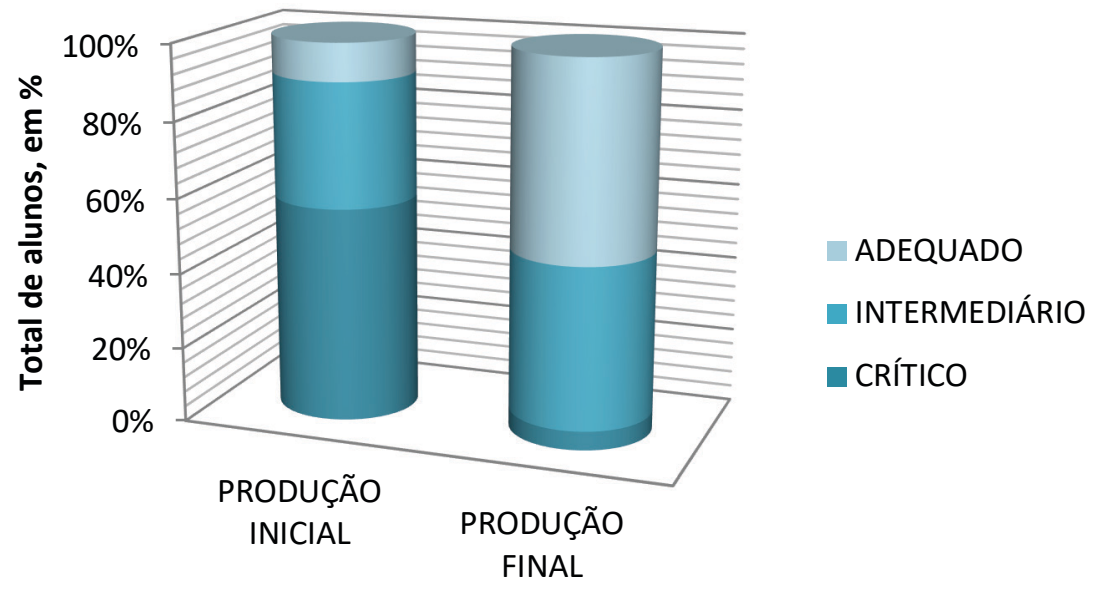

Gráfico 1 - Resultados P1 x P2

Fonte: pesquisa empírica (2015). 
O Gráfico 1 torna visível o aumento de alunos no nível recomendado, bem como o decréscimo de alunos no nível baixo, na produção final. Esses números revelam que, embora não tenhamos alcançado a totalidade de alunos em nível recomendado, houve progresso considerável no desempenho da turma.

Tais dados nos conduzem à observação de que a participação dos alunos no grupo Ponto de vista teve significativa contribuição para o desempenho obtido e avanços alcançados. Considerando que o grupo se configurou como espaço de práticas sociodiscursivas e de interação entre os membros, no debate sobre os temas em análise, acreditamos que aqueles que estavam mais envolvidos, lendo postagens e comentários e dando também a sua contribuição, por meio de comentários argumentativos, aprenderam muito sobre os temas, esclareceram dúvidas, (com)partilharam opiniões e, enfim, construíram, de forma colaborativa, o conhecimento.

\section{Considerações finais}

A observação da análise dos três corpora apresentados (produção inicial, logs das participações dos alunos no grupo Ponto de vista e produção final), mostram-nos que, embora não tenhamos conseguido superar totalmente o problema, houve considerável avanço da turma no que se refere à argumentação, após a aplicação do PEI. Assim, levando em consideração os resultados alcançados e, ainda, que nosso trabalho se pautou sobretudo nas interações via rede social, podemos afirmar, categoricamente, que o trabalho com as redes sociais na internet contribuiu sobremaneira para minimizar as dificuldades dos alunos no que concerne à produção de textos argumentativos.

Certamente, como esclarece Coscarelli (2005), a informática não faz mágica na educação. Dessa forma, não ignoramos os casos de alunos que não apresentaram avanço, mesmo diante de todas as ações desenvolvidos por meio do PEI. Não podemos cair na insensatez de acreditar que todos os problemas foram resolvidos, nem tampouco sermos falaciosos, a ponto de afirmar que todas as defasagens dos alunos (que remontam à fase da alfabetização, relacionadas à leitura, interpretação, conhecimentos linguísticos e escrita), foram solucionadas por meio de um projeto de intervenção que se estendeu por um trimestre. Lamentavelmente, há situações mais graves que demandam outras estratégias de intervenção

Dito isso, cumpre-nos reafirmar, mesmo em meio aos desafios enfrentados, que o trabalho com rede social, ao proporcionar a participação ativa dos estudantes, conferindo-lhes 
voz por meio de seus comentários, favoreceu o desenvolvimento de uma prática pedagógica menos tradicionalista. Desse modo, o conjunto de ações desenvolvidas não se reduziu à transmissão de informações, mas fomentou a construção do conhecimento. Permitiu, pois, que os estudantes operassem como coautores do conhecimento, por meio de uma aprendizagem mais colaborativa e participativa, o que contribuiu, até mesmo, para reduzir problemas relacionados à disciplina.

É válido destacar, nesse sentido, a importância da mediação do professor, sem a qual o trabalho certamente não alcançaria resultados exitosos. Desse modo, salientamos que, na condução das atividades, a intervenção pedagógica se faz necessária e indispensável, haja vista que, por meio dela, as discussões via rede social se tornam mais produtivas. O trabalho com redes sociais, então, não prescinde, de maneira alguma, da atuação do professor, o qual deve sugerir, instigar e incentivar o aluno a fazer novas descobertas, bem como direcionar e conduzir as práticas discursivas, facilitando e motivando, então, a (inter)aprendizagem.

\section{Referências}

BAKHTIN, M. Marxismo e filosofia da linguagem. 8. ed. São Paulo: Editora Hucitec, 1997.

BRASIL. Secretaria de Educação Fundamental. Parâmetros Curriculares Nacionais: terceiro e quarto ciclos do Ensino Fundamental: Língua Portuguesa. Brasília: MEC/SEF, 1998.

BRIGGS, A.; BURKE, P. Uma história social da mídia: de Gutenberg à Internet. Trad. Maria Carmelita Pádua Dias. Rio de Janeiro: Jorge Zahar, 2004.

CHARAUDEAU, P. Linguagem e discurso: modos de organização. 2. ed. São Paulo: Contexto, 2010.

COSCARELLI, C. V. Alfabetização e letramento digital. In: COSCARELLI, C. V.; RIBEIRO, A. E. (Org.). Letramento digital. Belo Horizonte: Ceale; Autêntica, 2005, p. 25-40.

GARCIA, O. M. Comunicação em prosa moderna: aprenda a escrever, aprenda a pensar. 24. ed. Rio de Janeiro: FGV, 2004.

GOMES, A. S. et al. Colaboração, comunicação e aprendizagem em rede social educativa. In: XAVIER, A. C. et al. Hipertexto \& Cibercultura: links com literatura, publicidade, plágio e redes sociais. São Paulo: Respel, 2011.p. 235-271.

HUTCHINS, E. Distributed cognition. In: SMELSER, N. J.; BALTES, P. B. (Org.). International encyclopedia of the social and behavioral sciences. Oxford: Elsevier Sciences, 2001. DOI: https://doi.org/10.1016/B0-08-043076-7/01636-3

KOCH, I. V. Argumentação e linguagem. 4. ed. São Paulo: Cortez, 1996.

KOCH, I. V. Introdução a linguística textual: trajetória e grandes temas. 2. ed. São Paulo: WMF Martins Fontes, 2009. 
LORENZO, E. M. A utilização das redes sociais na educação: importância, recursos, aplicabilidade, dificuldades. 2011. Disponível em: <http://www.clubedeautores.com.br/book/50369-a utilizacao_das_redes_sociais_na_Educação>. Acesso em: 01 maio 2014.

MACEDO, L. Desafios à prática reflexiva na escola. Pátio. Ano VI, 23, 2002. p. 12-15.

MARCUSCHI, L. A. Gêneros textuais emergentes no contexto da tecnologia digital. In: MARCUSCHI, L. A.; XAVIER, A. C. (Org.). Hipertexto e gêneros digitais: novas formas de construção de sentidos. 3.ed. São Paulo: Cortez, 2010, p. 15-80.

MINAS GERAIS. Secretaria de Estado de Educação. CBC de Língua Portuguesa: Ensino Fundamental. Belo Horizonte: Secretaria de Estado de Educação, 2008.

MONTES CLAROS. Secretaria Municipal de Educação. Proposta Curricular do Sistema Municipal de Ensino de Montes Claros - Ensino Fundamental - Anos Finais. Montes Claros: PMMC, 2014.

RECUERO, R. Redes sociais na internet. Porto Alegre: Sulina, 2009.

RIBEIRO, A. E.; ALVARENGA, P. J. L. O professor e o avatar do professor nas redes sociais. In: SIMPOSIO HIPERTEXTO E TECNOLOGIAS NA EDUCAÇÃO: REDES SOCIAIS E APRENDIZAGEM, 3.2010 .2 Anais... 2 Disponível em:

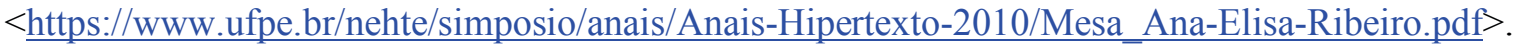
Acesso em: 8 set. 2014.

RIBEIRO, A. E. F. Navegar lendo, ler navegando: aspectos do letramento digital e da leitura de jornais. Tese (Doutorado em Estudos Linguísticos, Linguagem e Tecnologia) - Faculdade de Letras, UFMG, Belo Horizonte, 2008.

RIBEIRO, M. M.; ARAÚJO, J. C. “Tia, eu já escrevi o site do 'rotimeio'. Agora é só apertar o enter”: o endereço eletrônico na sala de aula. In: RODRIGUES-JUNIOR et al. Internet \& ensino: novos gêneros, outros desafios. 2. ed. Rio de Janeiro: Singular, 2009, p. 165-178.

ROJO, R.. Pedagogia dos multiletramentos: diversidade cultural e de linguagens na escola. In: ROJO, R.; MOURA, E. Multiletramentos na escola. São Paulo: Parábola, 2012. p. 11-31.

SCHNEUWLY, B.; DOLZ, J. et al. Gêneros orais e escritos na escola. Trad. R. H. R. Rojo e G. S. Cordeiro. Campinas: Mercado de Letras, 2004.

THIOLLENT, M. Metodologia da pesquisa-ação. 14. ed. São Paulo: Cortez, 2005.

VYGOTSKY, L. S. Formação social da mente. Trad.: J. C. Neto, L. S. M. Barreto, S. C. Afeche. 6. ed. São Paulo: Martins Fontes, 2002.

XAVIER, A. C. As tecnologias e a aprendizagem (re)construcionista no século XXI, 2005. Disponível em: $<$ http://www.hipertextus.net/volume1/artigo-xavier.pdf> $>$. Acesso em: 8 set. 2014. 